\title{
Propagation of a lithospheric tear fault (STEP) through the western boundary of the Calabrian accretionary wedge offshore eastern Sicily (Southern Italy)
}

\author{
Flora Gallais ${ }^{a}$, David Graindorge ${ }^{b, c}$, Marc-André Gutscher ${ }^{b, c, *}$, Dirk Klaeschen ${ }^{d}$ \\ a Ifremer Centre de Brest, Laboratoire Géodynamique et Géophysique, Géosciences Marines, B.P. 70, 29280 \\ Plouzané Cedex, France \\ ${ }^{\mathrm{b}}$ Université Européenne de Bretagne, France \\ ' Université de Brest, CNRS, UMR 6538 Domaines Océaniques, Institut Universitaire Européen de la Mer, Place \\ Nicolas Copernic, 29280 Plouzané, France \\ ${ }^{\mathrm{d}}$ Helmholtz-Zentrum für Ozeanforschung Kiel (GEOMAR), Dynamik des Ozeanbodens, Wischhofstr. 1-3, 24148 \\ Kiel, Germany \\ *: Corresponding author : Marc-André Gutscher, Tel.: + 33298498727 ; fax: + 33298498760 ; \\ email address : gutscher@univ-brest.fr
}

\begin{abstract}
:
The rollback of a segmented slab of oceanic lithosphere is typically accompanied by vertical lithospheric tear fault(s) along the lateral slab edge(s) and by strike slip movement in the upper plate, defined as a STEP fault (Subduction Tear Edge Propagator). The Neogene evolution of the Central Mediterranean is dominated by the interaction between the slow Africa-Eurasia convergence and the SE-ward rollback of the lonian slab, that leads to the back-arc opening of the Tyrrhenian Sea. Here, we present post-stack time migrated and pre-stack depth migrated Archimede (1997) multichannel seismic lines, that were acquired offshore eastern Sicily, at the foot of the Malta escarpment. First, we identify the recent deformation along the lateral ramp of the Calabrian accretionary wedge. Towards the east, the Calabrian wedge is formed by the accretion of the post-evaporitic sediments, above a decollement at the base of the Messinian evaporites. At the latitude of Syracuse, $50 \mathrm{~km}$ east of the Malta escarpment, a major $\mathrm{N} 150^{\circ} \mathrm{E}$ trending crustal scale and vertical fault slices through the entire accretionary wedge. This fault cuts by several kilometers, through the pre-evaporitic Messinian sediments and into the basement. The vertical offset along this vertical fault decreases from north to south, and the fault is no longer observed on the seismic lines, $50 \mathrm{~km} \mathrm{SE}$ of the Alfeo seamount. A previously published Moho depth isocontour map, offshore Sicily and the recent GPS data, combined with the presence of strike slip movements NE onshore Sicily, allow us to identify this $200 \mathrm{~km}$ long crustal-scale fault as the surface expression of a STEP fault. The presence of syntectonic Pleistocene sediments on top this crustal-scale fault suggests a recent lithospheric vertical movement of the STEP fault, in response to the rollback of the Ionian slab and to the SE-ward advance of the CalabriaPeloritan block.
\end{abstract}

\section{Highlights}

Depth migrated seismic reflection profiles from the Calabria/Sicily active margin. A N150 $\mathrm{E}$ striking, lithospheric scale fault, $50 \mathrm{~km}$ east of the Malta escarpment Interpreted to be a "Subduction Tear Edge Propagator" (STEP) fault - Fault offset decreases to the $S$ until termination (at the propagating tip) $\$ Deformed sediments suggest recent fault activity (related to Calabrian subduction).

Keywords: Tear fault ; Rollback ; Accretion ; Multi-channel seismic reflection 


\section{Introduction}

Since $80 \mathrm{Ma}$, the Mediterranean region has been affected by the very slow convergence of Africa towards stable Eurasia (1-2 cm/yr) (Dercourt et al., 1986; Dewey et al., 1989). During the last $30 \mathrm{Ma}$, the Western and Central Mediterranean were shaped by the trench rollback of the African subducting slab (Rehault et al., 1984; Malinverno and Ryan, 1986; Faccenna et al., 2001a; Faccenna et al., 2004). This leads to the formation of the highly arcuate orogenic belts surrounding by young oceanic basins (Faccenna et al., 2004). In the Central Mediterranean, the Ionian portion of the segmented African slab and the arched belt of Calabria are known to attain their current positions mostly between the late Miocene Pleistocene, as a consequence of the slab rollback (Faccenna et al., 2001b; Rosenbaum and Lister, 2004; Rosenbaum et al., 2008). However, the lateral movements between the Calabrian 'retreating' block and its "fixed" Apulian and Hyblean-Sicilian edges, as well as the location of the exact limits of the intervening boundaries are all topics of heated debate, and thus require further investigation. The aim of this paper is to study the deep to superficial morphological expression(s) of these lateral movements, in particular offshore eastern Sicily. To address this problematic, we present newly processed seismic lines from the Archimede survey (1997, R/V Le Nadir). The results obtained are combined with the onland studies and other geophysical data (e.g. wide-angle seismic, tomographic images) to propose a structural interpretation of the superficial to deep features present onshore NE Sicily and offshore Sicily.

2. Kinematics of vertical slab tearing: propagation of a STEP fault (Subduction Tear Edge Propagator) 
When subduction rollback occurs, it can be associated with a segmentation of the subducting slab (Govers and Wortel, 2005; Rosenbaum et al., 2008). Then one or more sub-vertical, lithospheric-scale tear faults can develop between the adjacent portions of the subducting plate (Figure 1) (Govers and Wortel, 2005). Such lithospheric tear faults and the trace they leave in the upper plate were defined as STEP (Subduction Tear Edge Propagator) faults (Govers and Wortel, 2005). In general, STEP faults can be identified by two characteristic types of deformation:

(1) strike-slip motion in the upper plate(s),

(2) and vertical motion between the more steeply subducting (oceanic) segment of the downgoing plate and the adjacent portion of the plate (Figure 1).

STEP faults can develop either in purely oceanic domains, as along both boundaries of the South Sandwich trench or along the northern boundary of the Tonga subduction zone (Govers and Wortel, 2005; Baes et al., 2011). However, they commonly develop along the ContinentOcean Boundaries (COB) of the same lithospheric plate, as in the South America - Caribbean plate boundary example (Clark et al., 2008a).

Such large-scale lithospheric faults can often form strike-slip plate boundaries on the upper plate(s) allowing differential motion of two distinct blocks: one advances, in response to the rollback of the subducting slab, while the adjacent plate remains relatively stationary (Figure 1). The existence of lithospheric tear faults had been proposed to explain the opening of backarc basins, caused by slab rollback, and the associated motion of independent continental blocks in the Mediterranean region, in particular the Tyrrhenian Sea - Calabria - Ionian Sea subduction system (Gvirtzman and Nur, 1999b; Rosenbaum and Lister, 2004).

3. Geological setting of the Calabrian subduction zone 
The Calabrian subducting slab is marked by a narrow $250 \mathrm{~km}$ wide and $500 \mathrm{~km}$ deep Wadati-Benioff zone, dipping at about $70^{\circ}$ toward the northwest (Giardini and Velona, 1991; Selvaggi and Chiarabba, 1995; Chiarabba et al., 2005). Since the Oligocene, the Calabrian trench has rolled back towards the E-SE by more than $800 \mathrm{~km}$ at an average rate of $2-3 \mathrm{~cm} / \mathrm{yr}$, triggered by the lateral tearing of the Calabrian slab (Malinverno and Ryan, 1986; Faccenna et al., 2001a; Faccenna et al., 2004). This leads to the opening of the Liguro-Provençal basin between 30-16 Ma and after a period of tectonic quiescence, of the Tyrrhenian basin from 12$10 \mathrm{Ma}$ to the present ((Faccenna et al., 2001a; Faccenna et al., 2004) and references cited in these papers). Spreading in the Tyrrhenian back-arc basin occurred during two distinct episodes: first within the Vavilov basin (4.3-2.6 Ma) (Kastens and Mascle, 1990) and second within the Marsili basin ( 2-1 Ma) (Figure 2) (Nicolosi et al., 2006; Guillaume et al., 2010). The Marsili basin opened at a rapid rate, probably during the fast $15^{\circ}-25^{\circ}$ clockwise rotation of the Calabrian Arc (Figure 2) (Speranza et al., 1999; Speranza et al., 2003; Cifelli et al., 2007; Cifelli et al., 2008).

At depth, the subduction history of the Calabrian subduction zone is indicated by vertical tomographic imaging of the African - Ionian Tethyan age oceanic lithosphere subducting beneath the Southern Tyrrhenian Sea (Lucente et al., 1999; Wortel and Spakman, 2000; Piromallo and Morelli, 2003). The horizontal seismic tomography images reveal two slab windows in southern Italy: one beneath the southern Apennines ( 150 km width) and the other one beneath north-eastern Sicily (Lucente et al., 1999; Wortel and Spakman, 2000; Piromallo and Morelli, 2003; Chiarabba et al., 2008; Neri et al., 2009). These asthenospheric windows were associated with the occurrence of vertical lithospheric tears (STEP fault) (Guarnieri, 2006; Rosenbaum et al., 2008).

Nowadays, in the southern Tyrrhenian region, the slow rate Africa/Eurasia convergence leads the formation of an active compressional tectonic ridge, located offshore North of Sicily (Billi 
et al., 2007; Billi et al., 2011). Onshore NE of Sicily, a set of geological features suggest the presence at depth of a STEP type lithospheric tear-fault. The dextral Taormina Line (AmodioMorelli et al., 1976; Rosenbaum and Lister, 2004; Rosenbaum et al., 2008) and the TindariLipari (TL) line (Guarnieri, 2004; Billi et al., 2006; Guarnieri, 2006; Bortoluzzi et al., 2010) have been proposed to be the crustal expression in upper plate of a STEP fault (Figure 2), that accommodate the remaining active portion of the slab beneath Calabria (Billi et al., 2006). In fact, recent GPS measurements show that a small amount of east-west extension still occurs in the Tyrrhenian basin, but only in its south-eastern most sector (Serpelloni et al., 2005; Serpelloni et al., 2007). This suggests that the SE-ward rollback of the Ionian slab is still active, but at very slow rates, as attested by the $3-4 \mathrm{~mm} / \mathrm{yr}$ movement of the GPS stations in Calabria with respect to a fixed Hyblean-Malta Plateau (Figure 2) (D'Agostino et al., 2011; Devoti et al., 2011; Palano et al., 2012). Furthermore, the formation of Mount Etna has been interpreted as a consequence of asthenospheric flow from Africa toward the Tyrrhenian, causing mantle flow through an asthenospheric window (Gvirtzman and Nur, 1999a; Faccenna et al., 2011). Indeed, such flow was recently invoked to explain the uplift of the Calabrian region since 700000 yr (Faccenna et al., 2011).

Offshore Sicily, in the Ionian Sea, the evidence of vertical motion between the more steeply Ionian oceanic subducting segment of the African downgoing plate and the adjacent Sicilian continental portion of the African plate was also reported (Cernobori et al., 1996; Hirn et al., 1997; Argnani, 2000; Nicolich et al., 2000; Argnani and Bonazzi, 2005; Govers and Wortel, 2005; Argnani, 2009; Polonia et al., 2011). Two distinct interpretations are still proposed concerning the position of the STEP fault beneath the Ionian Sea (Figure 2): first along the NNW-SSE oriented Malta escarpment (Argnani, 2000; Argnani and Bonazzi, 2005; Govers and Wortel, 2005; Argnani, 2009), second along a NW-SE crustal fault $50 \mathrm{~km}$ further to the east of this escarpment (Figure 2) (Cernobori et al., 1996; Hirn et al., 1997; Nicolich et al., 
2000; Polonia et al., 2011). Below, we offer new constraints that favour one of these interpretations and then discuss the geodynamic implications of the presence of a STEP fault (lithospheric tear fault) at the edge of the Ionian slab.

4. The 96-channel Archimede survey and processing of the data

The Archimede survey was conducted during ${ }^{\text {th }}$ to $2^{4 \text { th }}$ April 1997 onboard R/V Le Nadir. The objectives were to image the deep structure of the Calabrian accretionary wedge and adjacent region. Data were recorded by a 96-channel $2.4 \mathrm{~km}$ long streamer. The shot spacing of 50 meters and the 25 meters between each hydrophone provide a 24 -fold coverage, with a Common Mid Point (CMP) spacing of $12.5 \mathrm{~m}$. The seismic data were acquired with a $4 \mathrm{~ms}$ sampling rate $(250 \mathrm{~Hz})$. The source was an airgun array consisting of ten airguns for a total volume of $1220 \mathrm{cu}$.in, operating in a single-bubble mode (Avedik et al., 1996) and placed at a depth of 20 meters. In contrast to tuned arrays, this kind of system exploits the strong energy contained in the first bubble pulse delaying the firing of guns as a function of their volume in order to synchronize the output of the guns with respect to this first pulse (Avedik et al., 1996). The single-bubble method generates a powerful low frequency signal (10 to $15 \mathrm{~Hz}$ ), which allows a better penetration of waves to image the deep structures (Avedik et al., 1996; Bartolome et al., 2005).

The post-stack time migration of the profile Archimede 02 (Figure 2) was performed with the GeoVecteur Software@ developed by CGG (Compagnie Générale de Géophysique), particular attention was paid to improve the continuity of the deep reflectors. Table 1 lists the different processing steps which were applied to the Archimede 02 seismic sections discussed in this paper. A 6/8/55/65 pass-band and 49/50/51 notch filters, and a spherical divergence correction were applied after a spectral analysis of the small offset traces. Before stacking, a predictive deconvolution was applied to the signal with a typical window of $5 \mathrm{~s}$ TWT. This 
deconvolution attempts to predict and remove repetitions in the recorded seismograms, it also acts like an anti-multiple on many profiles (Yilmaz, 1987). A velocity analysis based on a semblance computation was performed each 300 Common Mid Point (CMP) (equal to 3.75 $\mathrm{km})$ to constrain the lateral velocity variations on the Archimede 02 seismic line. The velocity libraries obtained after interactive picking of these semblances were used to compute a Normal Move Out (NMO) correction. The NMO corrected CMP gather were stacked in order to increase the signal/noise ratio. After numerous tests of Kirchhoff migration using different constant and library of velocities, we finally conclude that the diffractions in particular due to the presence of salt are well corrected with a 2900 m/s constant velocity Kirchhoff migration (Hubral, 1977) (see Table 1 for a summary of this processing sequence).

The Archimede 16 and 17 profiles (Figure 2) were processed using iterative Pre-Stack Depth Migration (PSDM) to obtain a depth section. In the pre-processing prior to the depth migration special attention was paid to the multiple removal (see summary of the processing sequence listed in Table 2). The PSDM is a top to bottom approach with several iterations. In the first iteration, only an approximate water velocity needs to be assumed. During the migration focusing panels and Common Image Point (CIP) gathers (migrated CMP-gathers) were calculated. By the analysis of the focusing panels and the residual move-out of the CIPgather the correct water velocity can be determined and an estimation of the velocity (interval) of the first sediment layer is added into the macro model. With this new model (velocity of water and first sediment layer) the data are migrated again and new focusing panels were calculated (2nd iteration). For both profiles, Archimede 16 and 17, six iterations were needed to build the complete macro model. The PSDM not only provides a correct image in depth for these two lines, but also yields an internal velocity model for the interpretation. Based on these two detailed and geologically meaningful images, we can more 
precisely determine the extent of the salt-bearing Calabrian accretionary wedge and the correct geometry of the structure, in particular of the STEP fault.

\section{Results}

East of the major lineament, it was only possible to recognize stratigraphic units locally, where there are no complex tectonic disruptions above, and thus the sub-horizontal layered reflectors could be imaged (Figures 4 and 5). Based on facies comparison, the stratigraphic correlation was made following the interpretation given by Polonia et al. (2011) (Figure 3a) and Gallais et al. (2011). It allows identification of eight sedimentary layers deposited above the basement of the Ionian basin, that was interpreted as oceanic (Figure 3) (de Voogd et al., 1992). The Plio-Quaternary sediments overlay a chaotic body, that was interpreted as a lower Pliocene olistostrome by Polonia et al. (2011). On our dataset, this chaotic unit is present on the Archimede 16 and 02 lines beneath the Ionian foreland (Figures 5 and 6), its base is marked by the high amplitude A-reflector (Figure 3b) (Finetti, 1982). Below, the Messinian sequence is composed of three sub-layers: the Upper Unit, the Mobile Unit and the Lower Unit (Lofi et al., 2011) (Figure 3b) (Finetti, 1982). The underlying Tortonian sediments were deposited over the undifferentiated Tertiary sediments and the Mesozoic sediments (Figure $3 b)$.

The major structure identified on the Archimede seismic lines, that were shot at the western boundary of the Calabrian accretionary wedge is a steeply E-dipping, crustal scale fault (Figures 4 and 5). The pre-stack depth migrated E-W trending profile Archimede 17 (see position Figure 2) images this vertical crustal scale fault (sp 1300, Figure 4). The crustal scale fault sharply cuts the base of the Messinian evaporitic sediments (B-reflector) and the underlying group of pre-Messinian stratified and continuous reflectors, that is 2 to $2.5 \mathrm{~km}$ 
thick (Figure 4). The base of the Messinian evaporitic sediments is offset by $645 \mathrm{~m}$ along the crustal scale fault (base of Messinian Mobile Unit: 6700m - 6977m) (Figure 4). A half-graben basin develops on top of this fault (Figure 4). It is characterized by a westward dipping base and filled by a $\sim 645 \mathrm{~m}$ thick accumulation of syntectonic sediments (Figure 4 ). These syntectonic deposits were interpreted as Pleistocene in age (Cernobori et al., 1996; Hirn et al., 1997; Nicolich et al., 2000).

The pre-stack depth migrated E-W trending profile Archimede 16, shot south of the profile Archimede 17, also images the vertical crustal scale fault (sp 1000, Figure 5). However, the more southerly position of this profile Archimede 16 allows us to image the lateral ramp of the Calabrian accretionary wedge, located at the foot of the Malta escarpment (sp 230, Figure 5). The lateral ramp of the prism is a transparent fault zone, that corresponds to the deformation front of the Calabrian post-Messinian accretionary wedge. It is marked by undulations of the seafloor (Figure 5). This fault zone is associated with the activity of thrust and backthrust (sp 230, Figure 5). Some authors have proposed that this zone accommodates strike-slip movements (Minelli and Faccenna, 2010), which is in agreement with the interpretation of a lateral ramp. This lateral ramp separates the undeformed foreland, at the foot of the Malta escarpment to the west, from the rugous frontal slope of the Calabrian accretionary wedge, to the east (Figure 5). Towards the east, the Calabrian accretionary wedge thickens progressively above the decollement from $1 \mathrm{~km}$ to $3 \mathrm{~km} 40 \mathrm{~km}$ up to a distance of $40 \mathrm{~km}$ from the lateral ramp (sp 230 to 1050, Figure 5). This supports the notion that here, the base of the Messinian Mobile Unit marks the main decollement of the wedge (Ryan et al., 1982; Chamot-Rooke et al., 2005; Minelli and Faccenna, 2010; Polonia et al., 2011). Further east, the crustal scale fault sharply cuts the decollement and the underlying stratified pre-evaporitic reflectors down to the top of the crust at $\sim 9 \mathrm{~km}$ depth, as interpreted on other seismic lines (sp 1050, Figure 5) (Polonia et al., 2011). The offset is $275 \mathrm{~m}$ (base of 
Messinian Mobile Unit: 6795m - 7442m) (Figure 5) As northward, a half-graben basin, filled by Pleistocene deposits develops on top of this fault (Nicolich et al., 2000). Through correlation of this syntectonic half-graben basin with the ION-1 (Cernobori et al., 1996), CROP-M3 (Polonia et al., 2011) and Archimede 17 profiles and a set of profiles acquired further towards the NE (Nicolich et al., 2000) (see position on the Figure 3, inset map), this crustal fault could be followed over a distance of $200 \mathrm{~km}$. This E-dipping crustal vertical scale defines a $\mathrm{N}^{\circ} 150$ trending feature, that cuts through the western Ionian Sea and strongly affects the post-Calabrian accretionary wedge.

Numerous previous seismic studies proposed that the post-Messinian wedge is limited eastward by this vertical scale fault (Doglioni et al., 2001; Chamot-Rooke et al., 2005; Minelli and Faccenna, 2010). However, very recently other suggested that the contact between the post- and pre-Messinian wedges occurs further east (Polonia et al., 2011). Based on our seismic images and correlations with very recent results (Gallais et al., 2012), we also propose that the boundary between the post- and pre-Messinian wedge occurs $40 \mathrm{~km}$ east of the fault, along a W-dipping backthrust of the Calabrian accretionary wedge (sp 750, Figure 4 and sp 1700, Figure 5). On the line Archimede 17 (Figure 4), this interpretation is supported by the downstepping of the decollement observed below the backthrust. The decollement cuts through deeper sediments to reach $8 \mathrm{~km}$ depth, a feature also observed on the Archimede line 18 (see position inset, Figure 3) (Gallais et al., 2012). On the Archimede 16 profile (Figure 5), the $\mathrm{W}$-ward dipping major backthrust that delineates the boundary between the post- and preMessinian wedges is still present. It is still associated with a downstepping of the decollement from 6.5 to $8 \mathrm{~km}$ depth (Figure 5). On this profile, the velocities within the post-Messinian wedge clearly decreases abruptly on both sides of the E-dipping crustal scale fault. This might be linked with the activity of the fault that was active during the emplacement of the 
Calabrian accretionary wedge and may have facilitate the formation of a mélange body on this E-facing side. East of the backthrust, the pre-Messinian wedge is highly deformed quasi transparent body, marred by disrupted reflectors (Figures 4 and 5).

On the time migrated SW-NE trending profile Archimede 02 (Figure 6), shot south of the profile Archimede 16, no large vertical throw is observed (Figure 6A). However, this profile allows us to better describe the architecture of the Calabrian accretionary wedge. Below the foreland of the wedge, at the foot of the Malta escarpment, a 10 km broad incipient deformation zone develops (Figure 6B). Here, the base of the Plio-Quaternary, including the chaotic body (A-reflector) (Figure 3b) becomes gently folded approaching the lateral ramp of the Calabrian accretionary wedge (sp 2100, Figure 6). This corresponds to the proto-thrust domain of the Calabrian accretionary wedge (Figure 6B). Directly NE of the proto-thrust domain, the lateral ramp of the wedge is marked by a change from the flat foreland to the rugous frontal slope of the Calabrian accretionary wedge (Figure 6). Below the frontal slope, some SE verging thrusts are imaged within the Plio-Quaternary and the Messinian sediments (Figure 6). The post-evaporitic sediments (Messinian Upper and Mobile Units) are tectonically thickened by activity of these thrusts above the decollement (Figure 6). The decollement at the base of the Messinian evaporites dips gently towards the NE (Figure 6). Below this post-Messinian Calabrian wedge, the pre-evaporitic sediments correspond to a stratified and highly reflective group of continuous reflectors, that are $2 \mathrm{~s}$ TWT thick (Figure 6). We interpret the top of the Ionian oceanic crust to be at the base of this reflective sequence at $8 \mathrm{~s}$ TWT (Figure 6), in agreement with seismic reflection profiles and OBS data (Makris et al., 1986; Nicolich et al., 2000; Catalano et al., 2001). Here, no expression of a crustal scale fault and a major backthrust are still visible. 
This analysis reveals that the post-Messinian Calabrian wedge is cut by a E-dipping vertical and crustal scale fault, that offsets the base of the Messinian evaporitic sediments and the underlying pre-Messinian to Mesozoic sediments. The vertical throw along this $\mathrm{N} 150^{\circ}$ trending fault decreases towards the south (Figures 4 and 5). Within the domain comprised in between the lines Archimede 16 and 02, the crustal faults terminates. Following these interpretations, we will now discuss the tectonic significance of this crustal scale fault, which slices through the entire post-Messinian Calabrian prism.

\section{Discussion}

The discovery of a $\mathrm{N}^{\circ} 150$ trending crustal scale fault is not the novelty of this paper, since it was already mapped and described in previous studies (Figure 7) (Cernobori et al., 1996; Hirn et al., 1997; Nicolich et al., 2000; Chamot-Rooke et al., 2005; Minelli and Faccenna, 2010; Polonia et al., 2011). This work offers detailed structural constraints of the movement along this fault as well as a new hypothesis regarding its origin.

Some authors have proposed that its vertical geometry could be inherited from a former strike-slip fault (Cernobori et al., 1996; Nicolich et al., 2000). They further suggested that this fault was later reactivated as a normal fault, with down-to-the-east movement during the Pleistocene, as attested by the presence of a subsiding half-graben basin (Figure 7) (Cernobori et al., 1996; Nicolich et al., 2000). Other authors have recently proposed that this crustal scale fault could correspond to a STEP fault (Polonia et al., 2011).These interpretations will now be discussed based on the recent data acquired in the Central Mediterranean and on the concept of a STEP fault (Govers and Wortel, 2005) will be investigated.

Numerous structural studies and some focal mechanisms in NE Sicily (Figure 7) showed that dextral strike slip movement occurs between the Sicily - Hyblean block and the Calabrian - 
Peloritan (NE Sicily) block (Figure 7) (Guarnieri, 2004; Guarnieri, 2006). This is consistent with the very recent GPS measurements, that show that Calabria and the region NE Sicily still advances at significant rate of $\sim 2-3 \mathrm{~mm} / \mathrm{yr}$ towards the $\mathrm{SE}$, in response to the SE-ward rollback of the Ionian slab (Figure 2) (D'Agostino et al., 2011; Devoti et al., 2011; Palano et al., 2012). Moreover, the tomographic images reveal a negative velocity anomaly at the SW edge of the subducting Ionian lithosphere, which was interpreted as lithospheric tear fault (Lucente et al., 1999; Wortel and Spakman, 2000; Piromallo and Morelli, 2003; Chiarabba et al., 2008; Neri et al., 2009). Recent SKS splitting results reveal toroidal mantle flow beneath NE Sicily (Civello and Margheriti, 2004; Baccheschi et al., 2007; Baccheschi et al., 2011), and confirm the presence of an asthenospheric window in this region. The uplift and faulting in Calabria (Westaway, 1993) were recently proposed to be sustained dynamically by toroidal mantle flow (Gvirtzman and Nur, 2001; Faccenna et al., 2011). This process was associated with the retreat of the narrow Ionian slab and proposed to provide favorable conditions for decompression melting, leading to the Mt Etna volcanism (0.5 Ma to the present) (Gvirtzman and Nur, 1999a; Schellart, 2010). This field of results indicates that beneath the Ionian Sea, a lithospheric vertical tear must be present between the retreating Ionian oceanic lithosphere and the stable continental Sicily - Hyblean plateau to allow the rollback to continue. In the Ionian Sea, the position of the $\mathrm{N} 150^{\circ}$ trending fault, identified in this study correlates with a large vertical offset of the Moho (Figure 7) (Nicolich et al., 2000). Through correlation with other geophysical data, we propose that this $\mathrm{N}^{\circ} 150$ trending vertical fault is the surface expression of a vertical lithospheric tear, a STEP fault, that occurs at greater depth. In this framework, we further suggest that the motion along this fault may be a purely vertical movement. Thus, the Pleistocene syntectonic basin emplaced in response to this movement between the more steeply subducting Ionian slab and the adjacent "Sicilian" portion of the 
plate, without any normal component as previously proposed (Cernobori et al., 1996; Nicolich et al., 2000).

This leads us to propose that the south-western boundary of the Tyrrhenian - Calabrian Ionian subduction system is a good example of a STEP fault, with:

- $\quad$ strike-slip movement onshore NE Sicily, that accommodates in the upper plate the advance towards the SE of the Peloritan block attached to Calabria, relative to the stable Sicily - Hyblean plateau,

- lithospheric vertical movement beneath the Ionian Basin, that is transmitted at a crustal scale along the $\mathrm{N} 150^{\circ}$ trending vertical fault.

This lithospheric tear is consistent with the presence of an asthenospheric window, beneath NE Sicily and the SW lateral edge of the Ionian slab (Lucente et al., 1999; Wortel and Spakman, 2000; Piromallo and Morelli, 2003; Chiarabba et al., 2008; Neri et al., 2009). Toroidal mantle flow, due to this windows (Civello and Margheriti, 2004; Baccheschi et al., 2007; Baccheschi et al., 2011) successfully explains the position of the Mt Etna and its geochemical signature (oceanic basalt affinity) (Gvirtzman and Nur, 1999a; Schellart, 2010).

This study also reveals that in the Ionian Basin, the STEP fault is clearly distinct from the Malta escarpment (Figure 8), as previously proposed (Argnani, 2000; Argnani and Bonazzi, 2005; Govers and Wortel, 2005; Argnani, 2009). The N150 trending lithospheric STEP fault is located $\sim 50 \mathrm{~km}$ further east, at the latitude of Syracuse (Figure 7) (Nicolich et al., 2000; Polonia et al., 2011). It was proposed that the COB (Continent-Ocean Boundary) is marked by this $\mathrm{N}^{\circ} 150$ trending vertical fault, that propagates directly east of the sigmoidal Alfeo seamount (Figure 7). In fact, the rocks exposed along the Malta escarpment, which forms the continental slope of Sicily are of continental type and these continental fragments extend as far eastward as the Alfeo seamount (Figure 7) (Scandone et al., 1981). The multichannel 
seismic line ETNA5, which was recorded at the station VEN in the Hyblean plateau (see position on Figure 7), confirms that the COB (Continent-Ocean Boundary) across this margin occurs within a domain, lying in between the Malta escarpment and a vertical structure, located $30 \mathrm{~km}$ further to the east (Figure 8) (Nicolich et al., 2000; Chamot-Rooke et al., 2005). Following the ETNA-5 line, it seems that the position of the $\mathrm{N}^{\circ} 150$ trending fault could correspond to the abrupt transition between "thinned continental crust" and "oceanic crust" (see at distance $58 \mathrm{~km}$ on Figure 4 in Nicolich et al., 2000). Thus, this suggests that the fault may have propagated preferentially at the transition "thinned continental crust/oceanic crust" rather than at the transition "continental crust/thinned continental crust", lying at depth beneath the Malta escarpment (Figure 8) (Nicolich et al., 2000). Unfortunately, the quality of the OBS data (Makris et al., 1986) in this sector and the profile ETNA5, do not offer the sufficiently detailed evidence to confirm this hypothesis. At this stage, it seems that the STEP fault propagates through the inherited weakness zone, that corresponds to the Mesozoic margin of the Ionian Basin, East of Sicily (Frizon de Lamotte et al., 2011; Gallais et al., 2011), as in South America - Caribbean (Clark et al., 2008b).

\section{Concluding remarks}

The Archimede multichannel seismic lines acquired on the western corner of the postMessinian Calabrian accretionary wedge allow us to better describe its architecture, that interacts with a crustal scale fault. We show that the lateral ramp of the wedge separates an undeformed foreland at the foot of the Malta escarpment, from the deformed Calabrian wedge. The prism progressively grows by accretion above the decollement, lying at the base of the Messinian evaporites. Further to the east, the wedge is dissected by a crustal scale and vertical fault, that offsets the crustal unit and the Mesozoic to the pre-evaporitic sediments. Activity of this faults leads to the formation, of a Pleistocene syntectonic basin. Through 
correlations with other seismic studies, we show that a $\mathrm{N}^{\circ} 150$ trending fault cuts more than $200 \mathrm{~km}$ into the Ionian Basin and that its vertical throw decreases towards the south. The southernmost termination of the $\mathrm{N} 150^{\circ}$ oriented fault can be followed as far south as the latitude $36.4^{\circ} \mathrm{N}$, but no further. A set of data obtained from geodetic, tomographic, geochemical, structural and seismic studies allows us to propose that the vertical movement observed along this crustal scale fault is the surface expression of a STEP fault.

This STEP fault accompanies both (a) the advanced of Peloritan - Calabrian towards the SE and (b) the SE-ward rollback of the Ionian slab, with:

(a) crustal dextral strike slip movement in NE Sicily between the stable Sicily Hyblean plateau and the Peloritan - Calabria block, as confirmed by earthquake focal mechanisms,

(b) lithospheric vertical movement beneath the Ionian western Sea, that propagates upward through a $\mathrm{N} 150^{\circ}$ trending crustal scale fault.

The whole dataset that was recently interpreted NE Sicily and in the western Ionian Sea, is consistent and shows the presence of a STEP fault at the SW edge of the Ionian Basin. We further suggest that this lithospheric tear propagates in the Ionian basin during the late Neogene, through the inherited Continent-Ocean Boundary, acquired during the formation of the Mesozoic passive margin of the basin.

\section{Acknowledgments}

We gratefully acknowledge Marc Schaming, Angélique Leprêtre and Laure Schenini their help for reading in reading these data with the GeoVecteur Software. We are grateful to Andrea Billi and to anonymous reviewers for their helpful comments and suggestions that improved the manuscript. The maps were drafted using the Generic Mapping Tools (GMT) software (Wessel and Smith, 1991). The first author gratefully acknowledges her colleagues 
from Geosciences Marine from Ifremer (Brest) onboard "Pourquoi Pas?" that give her support and a good atmosphere to finish the first revision (in particular Romain Pellen, Caesar Rigoti, Yohann Kergoat, the 0-4 team and Philippe Schnürle).

Figure captions
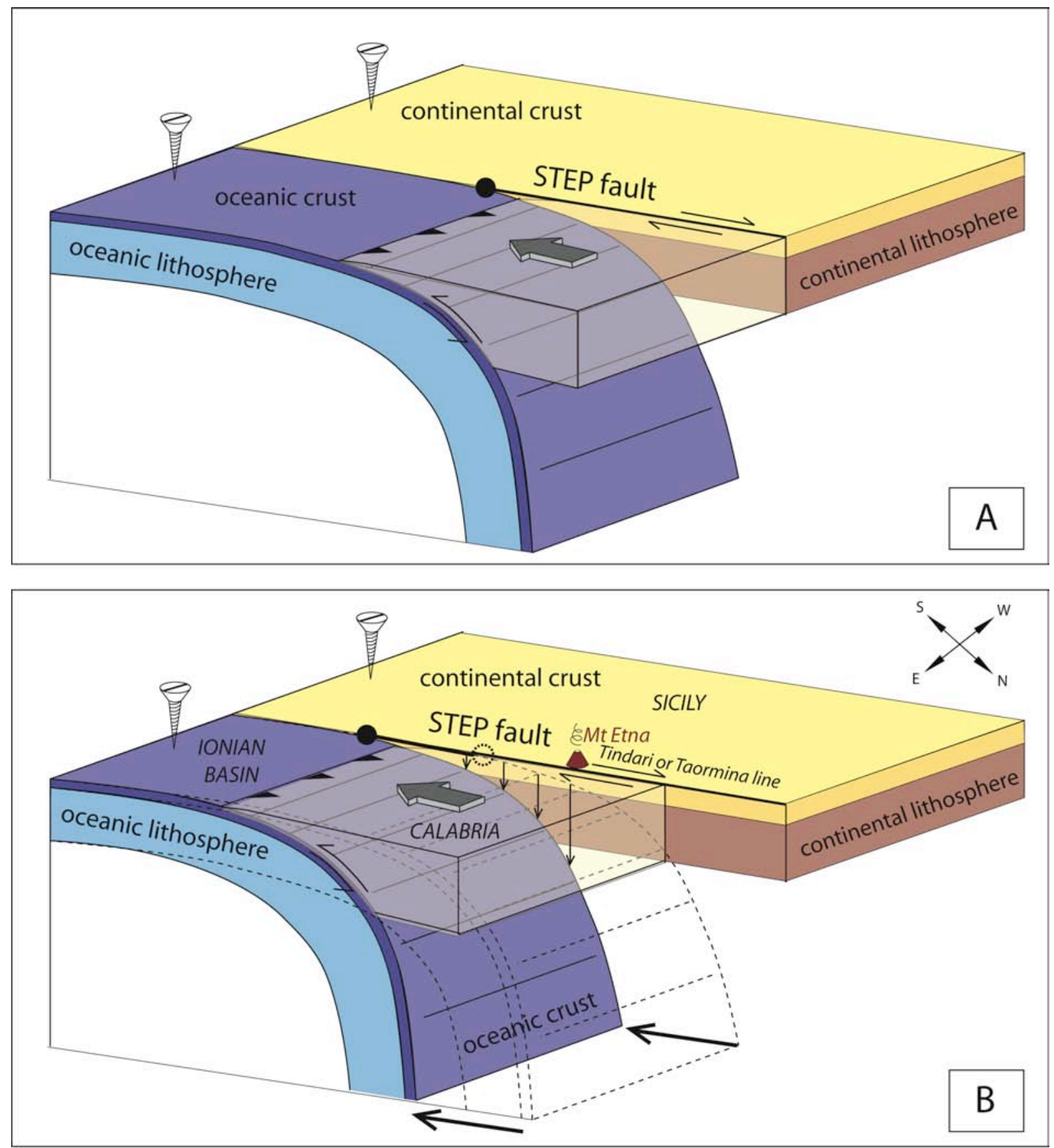

Figure 1: Schematic 3-D block diagram showing the plate and block motions related to a STEP (Subduction Tear Edge Propagator) fault. A: the initial situation with a continental 
domain adjacent to an oceanic domain together forming a single plate. The black circle indicates the tip of the propagating lithospheric tear fault. B: As the STEP fault propagates into the foreland, the oceanic portion of the plate separates from the continental portion, and descends into the mantle. In this particular case, there is no large-scale horizontal motion of the oceanic domain (note the screws indicating the absence of horizontal movement).

Subduction occurs purely through slab rollback. This induces the advance of a portion of the upper plate towards the oceanic domain. There is relative strike-slip motion between the independent block and the adjacent continental domain. Note that the amount of slab rollback, the advance of the independent block and the propagation distance of the tip of the STEP fault, are all approximately equal (and indicated by the thick arrows).

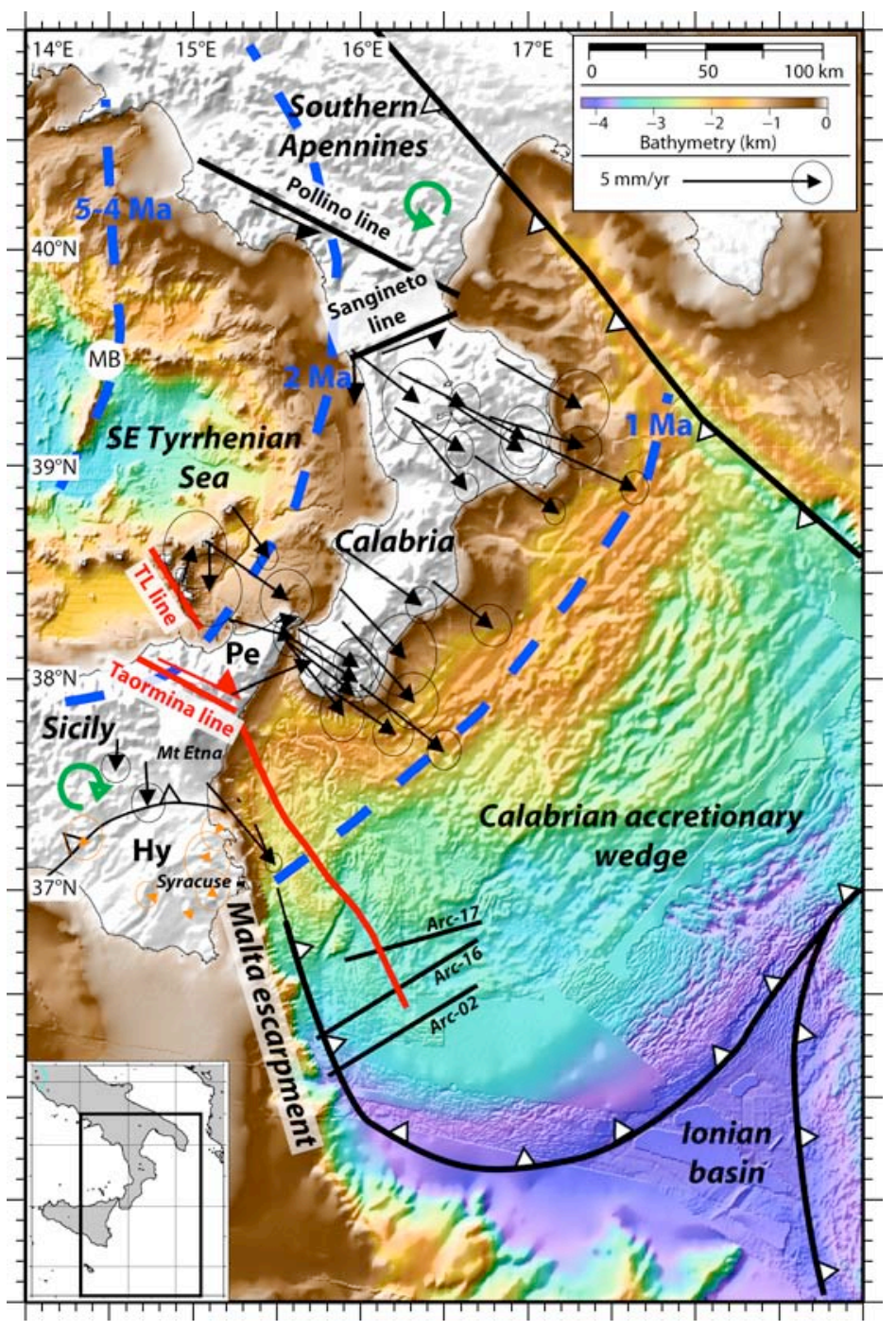


Figure 2: Structural map of the Central Mediterranean showing the Archimede seismic lines used in this study. Topography and bathymetry are from GEBCO 1 min dataset and Medimap Group Bathymetry compilation (Loubrieu et al., 2007). Black lines show major fault systems, modified from the Geodynamic Map of the Mediterranean http://ccgm.free.fr. GPS vectors with respect to a fixed Hyblean-Malta block, as defined by the sites shown in orange (Devoti et al., 2011). Thick curved blue lines: the SE movement of the Ionian portion of the segmented African slab according to (Faccenna et al., 2011). Green circle arrows: rotations observed in southern Apennines and Sicily (Speranza et al., 1999; Speranza et al., 2003; Mattei et al., 2007). MB: Marsili Basin; TL Line: Tindari-Lipari Line; Hy: Hyblean plateau; Pe: Peloritan mountains.

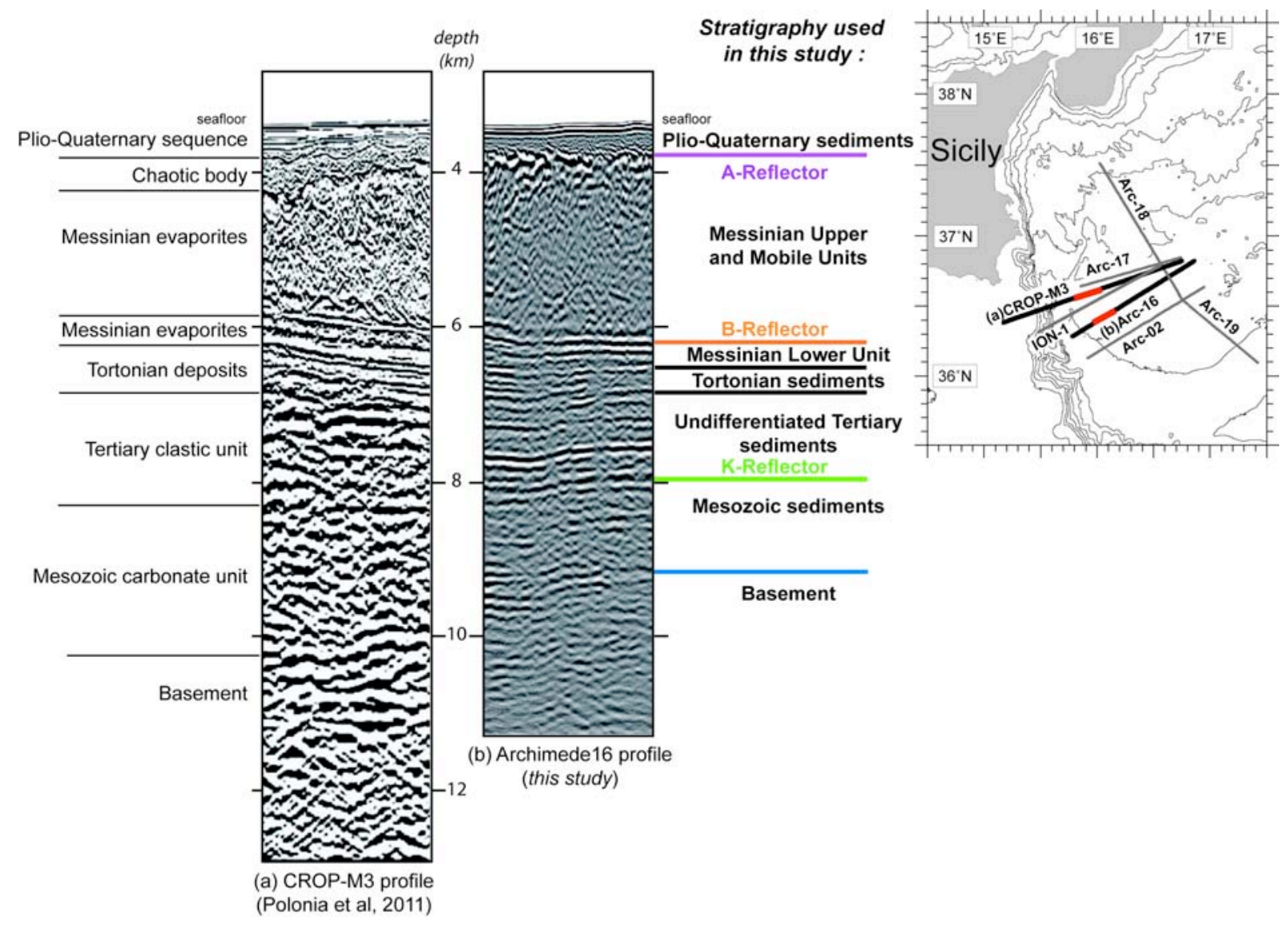

Figure 3: Seismic stratigraphy of the sedimentary section, identified on the CROP-M3 multichannel seismic reflection profile (a) (Polonia et al., 2011), correlated with the pre-stack depth migrated Archimede 16 profile (b). Note that the stratigraphy shown is the original 
interpretation and these are presented for this study at the same vertical scale in depth. Map inset shows the position of the seismic lines already published and used in this study (CROPM3 in (Polonia et al., 2011), , ION-1 in (Cernobori et al., 1996; Nicolich et al., 2000), Arc-18 and Arc-19 (Gallais et al., 2012)).
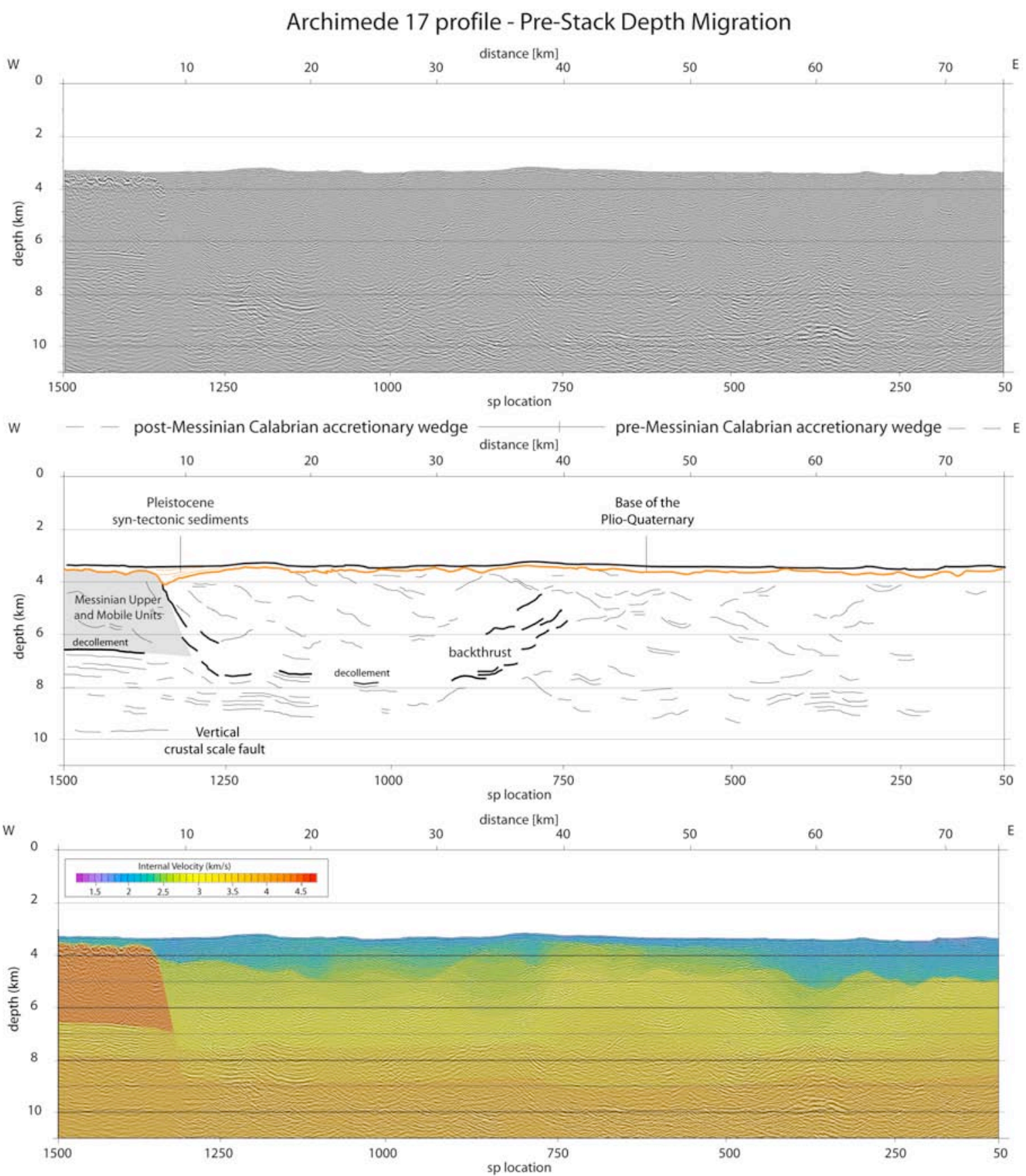

Figure 4: (top) Pre-stack depth migrated Archimede 17 profile (Vertical exaggeration 2) (see Figure 2 for its location). (middle) Line drawing. (bottom) Color-coded seismic velocities 


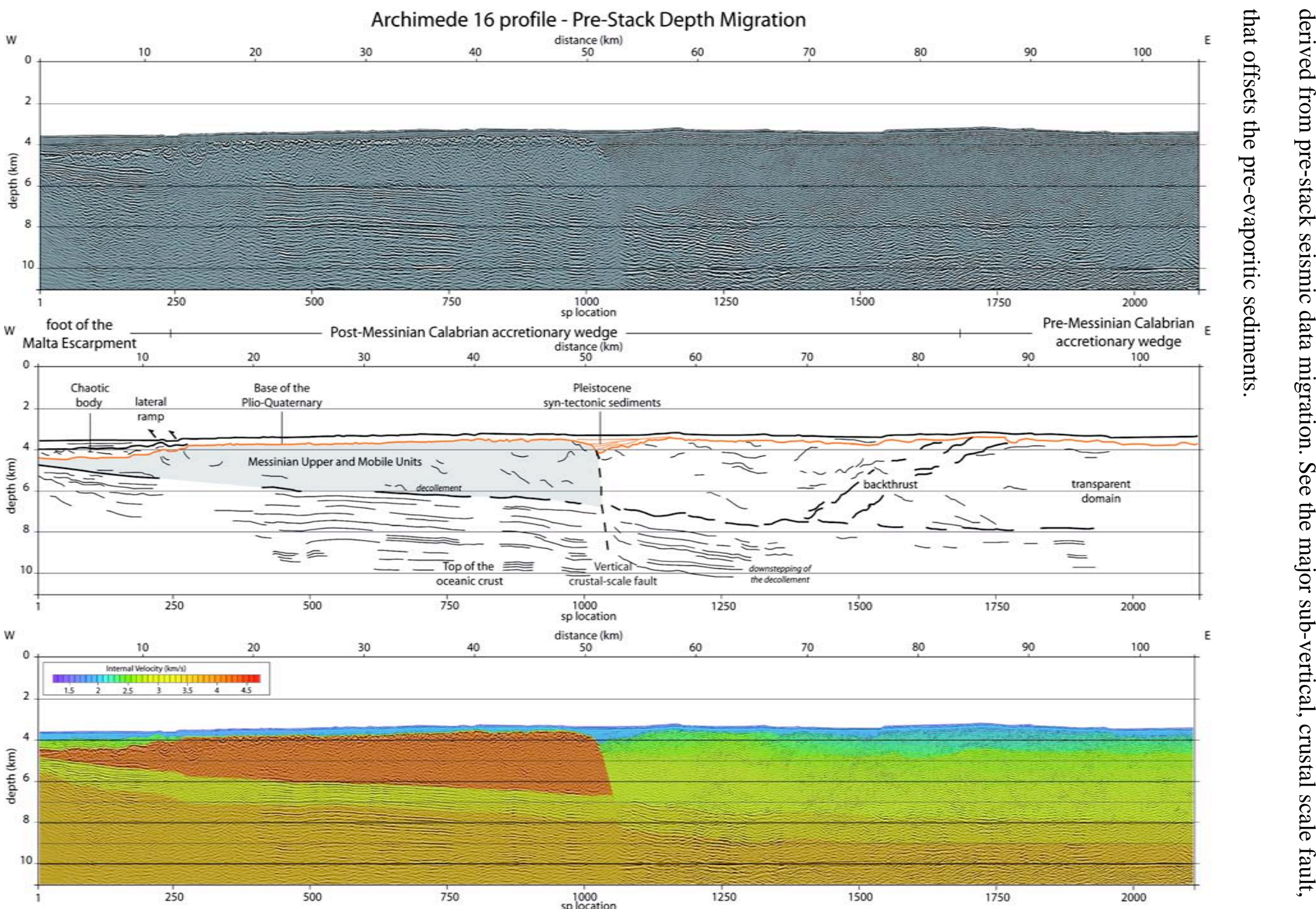


Figure 5: (top) Pre-stack depth migrated Archimede 16 profile (Vertical exaggeration 2) (see Figure 2 for its location). (middle) Line drawing. (bottom) Color-coded seismic velocities derived from pre-stack seismic data migration. See the lateral ramp of the Calabrian accretionary wedge and the major sub-vertical, crustal scale fault, that offsets the preevaporitic sediments. 
Foot of the Malta escarpment

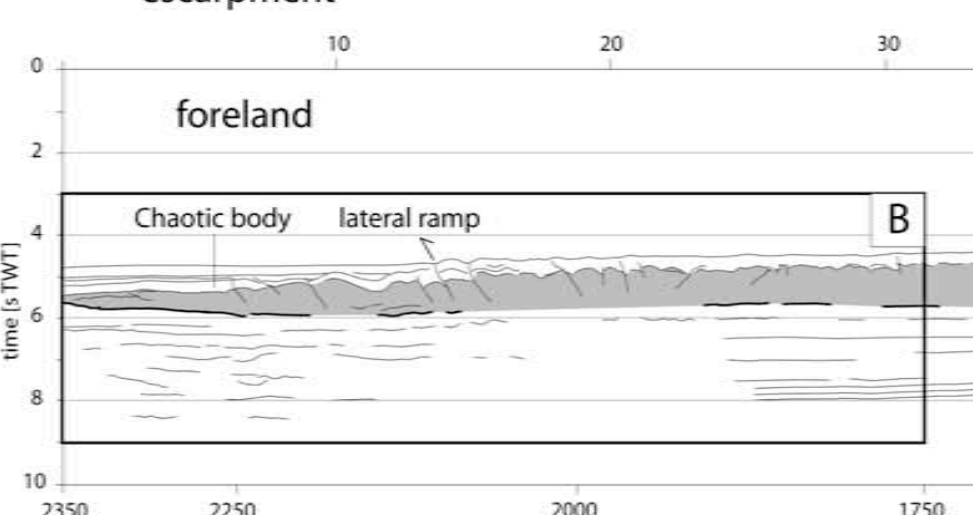

SW

$$
3
$$

B-The frontal slope - post-Messinian Calabrian prism

40

frontal slope
Base of the

prolongation of the "STEP" fault projected Plio-Quaternary

Base of the

Messinian Mobile Unit

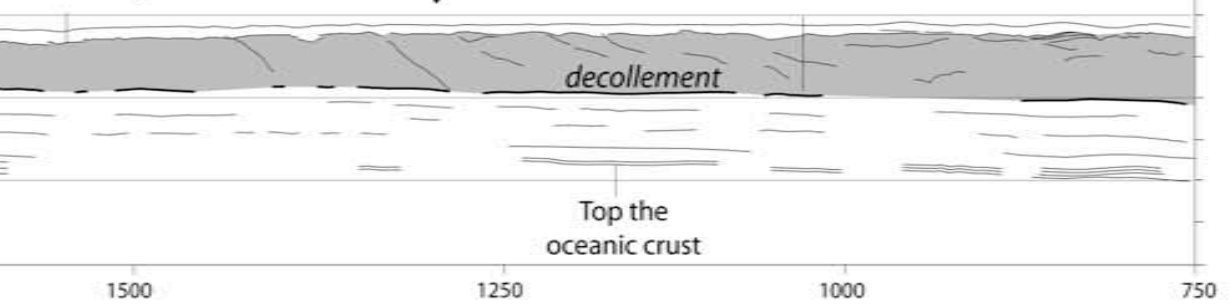

sp location

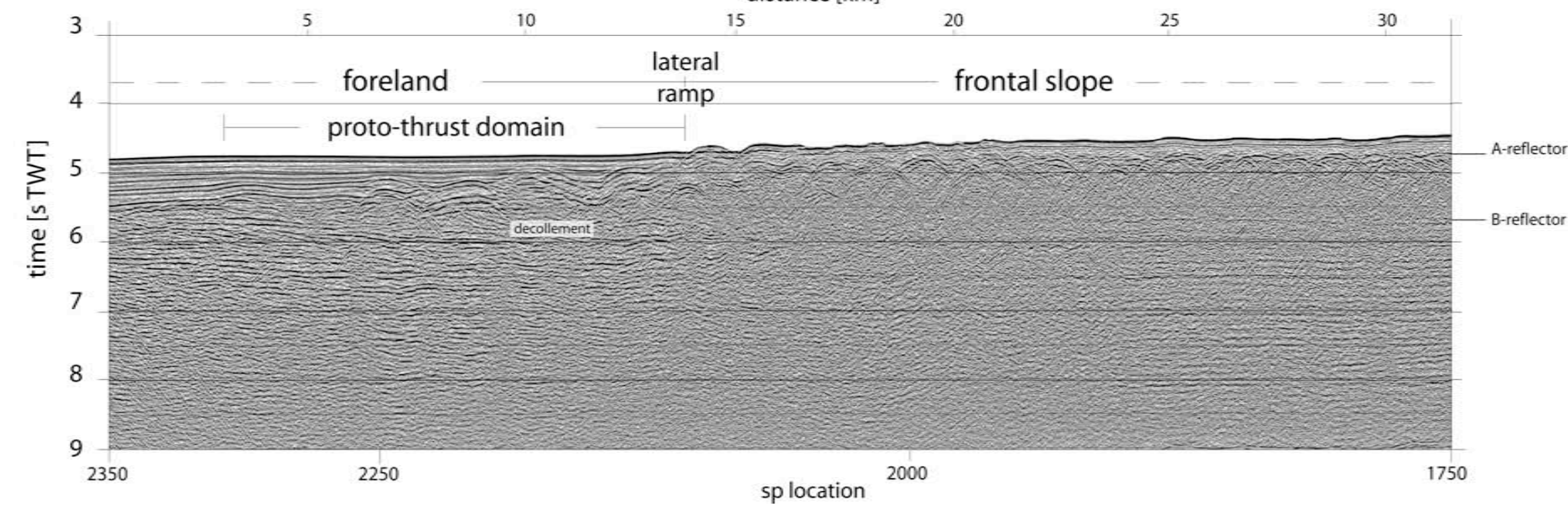


Figure 6: (A) Architecture of the western corner of the Calabrian accretionary wedge, a SW-

NE trending profile: Archimede 02 (Vertical exaggeration 2). (B) Note the highly reflective decollement of the post-Messinian Calabrian accretionary wedge, located at the base of the Messinian Mobile Unit (B-reflector).

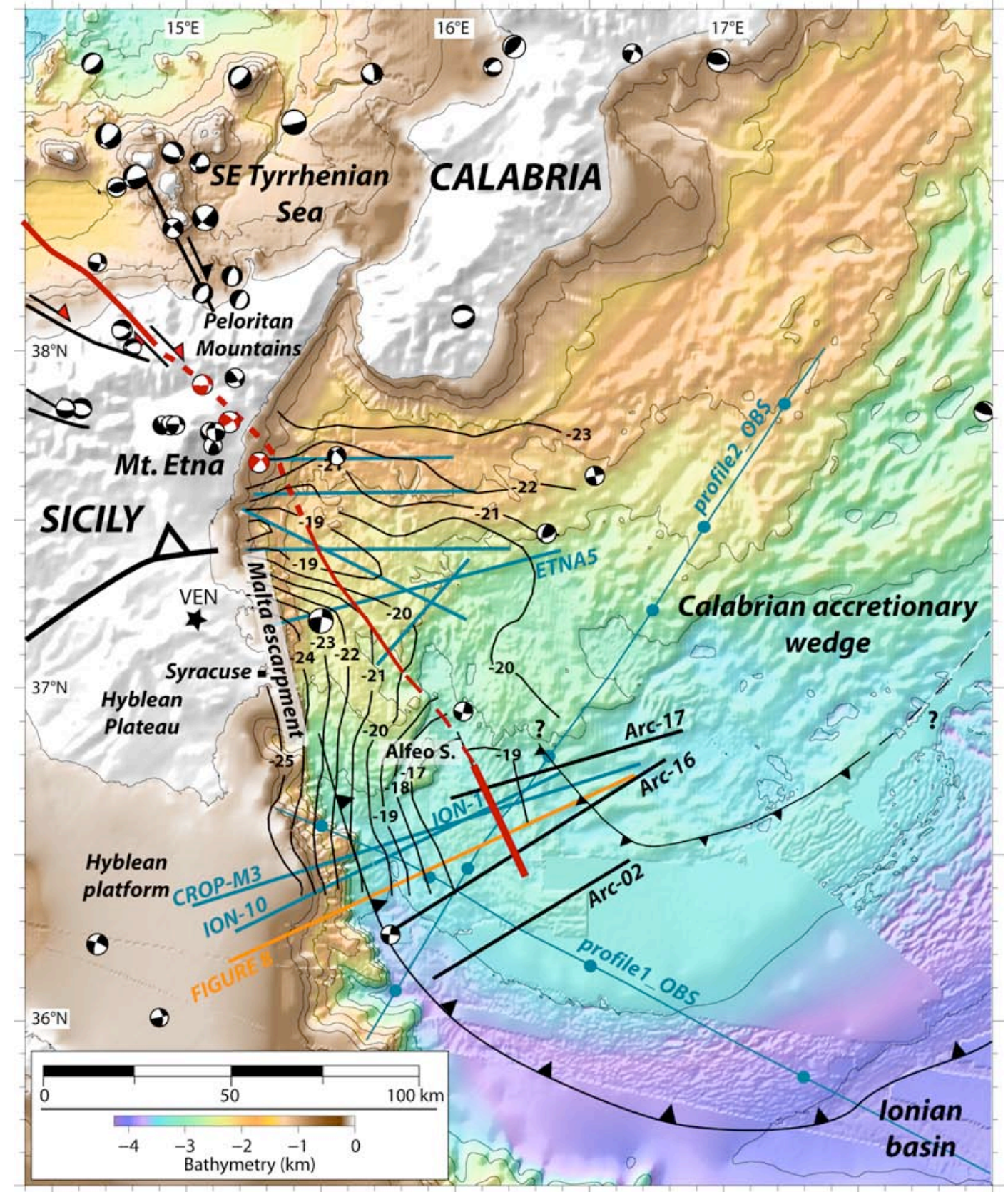

Figure 7: Map of the vertical crustal scale fault in the Ionian Sea (thick red line), correlated with previous seismic studies (fault F6 in Nicolich et al., 2000) and extended to the south by our study. Focal mechanisms from the CMT and RCMT catalog 
(http://www.bo.ingv.it/RCMT/Italydataset.html) (Pondrelli et al., 2006). In red focal

mechanism indicate strike slip movement NE Sicily. Structural interpretations onshore Sicily are taken from (Guarnieri, 2006). Thin black contours: isobaths in kilometers of the Moho (Nicolich et al., 2000). Note that the vertical and crustal scale fault together with the strike slip Taormina fault define the STEP, that bounds SW-ward the Ionian slab. See the position of the backthrust that is the boundary between the pre- and post-Messinian wedges. The position of schematic composite cross-section shown in Figure 8 is indicated in orange.
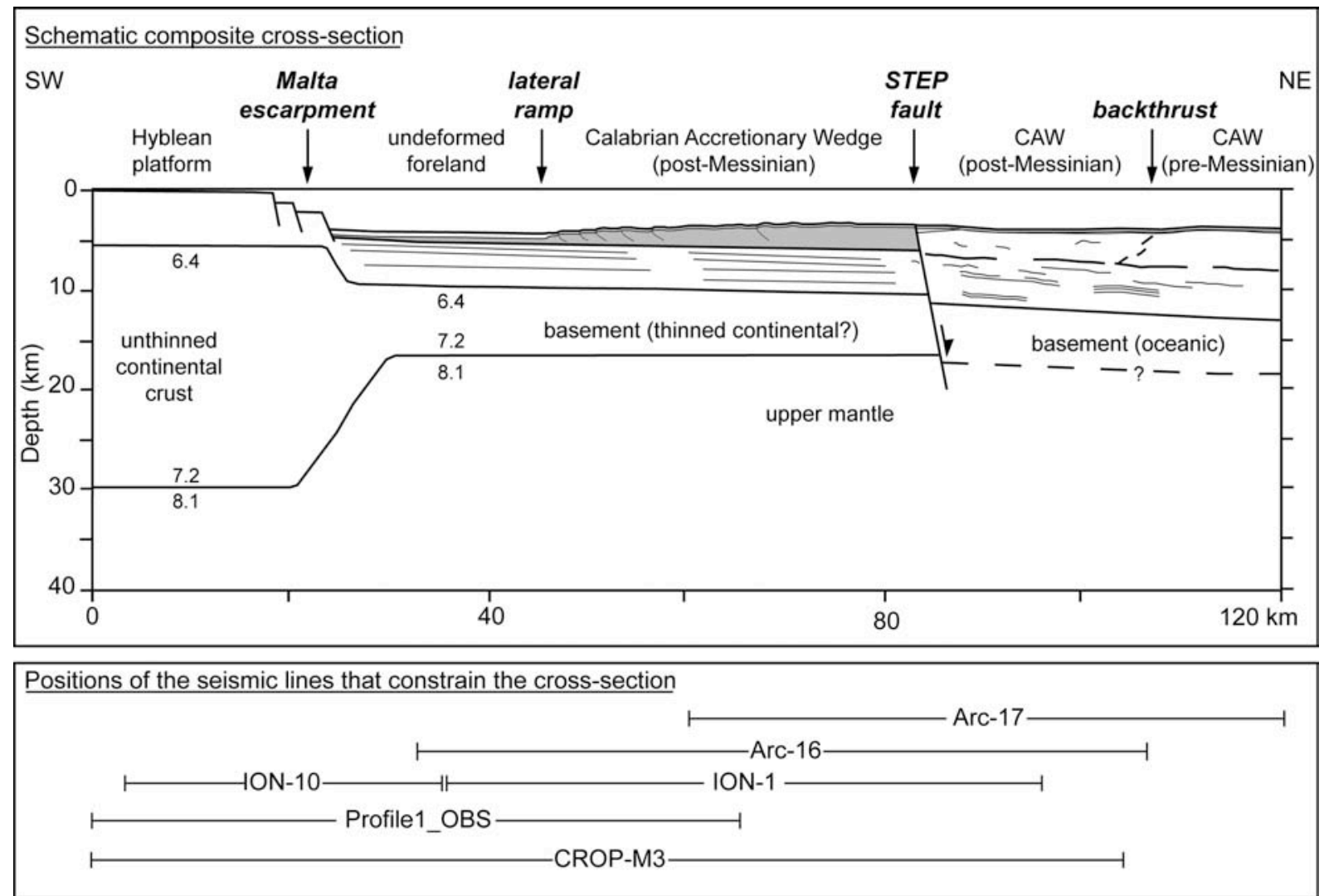

Figure 8: Schematic composite structural cross-section (No vertical exaggeration). The overall deep structure (basement, Moho) is constrained by the two refraction profiles, "profile_OBS" on the Figure 7 (Makris et al., 1986). The detailed shallow crustal structure (sedimentary basins, basement) is imaged by four multichannel seismic reflection profiles; two published previously ION-10 and ION-1 in time (Cernobori et al., 1996; Nicolich et al., 2000) and CROP-M3 in depth (Polonia et al., 2011) and the two depth migrated profiles Arc-16 and 
Wedge.

\begin{tabular}{|c|c|c|}
\hline Processing step & Parameters & Purpose \\
\hline Bandpass filtering & $4 / 6 / 55 / 60$ & $\begin{array}{l}\text { earth filtering, and absorption of high frequency } \\
\text { through depth }\end{array}$ \\
\hline Notch filtering & $49 / 50 / 51$ & remove the electrical noise \\
\hline Spherical divergence correction & & wave spherical divergence attenuation \\
\hline CMP sorting & Each $300 \mathrm{CMP}$ & \\
\hline Semblance & Choosing best velocities for stacking & velocity analysis \\
\hline Predictive deconvolution & $\begin{array}{l}\text { Prediction length usually between } 100 \text { and } \\
\qquad 150 \mathrm{~ms}\end{array}$ & to focus the signal and attenuate the multiples \\
\hline Highpass filtering & & $\begin{array}{l}\text { to remove high frequency introduced by } \\
\text { deconvolution }\end{array}$ \\
\hline Stack & & $\begin{array}{l}\text { to improve signal } / \text { noise ratio with a factor } \\
\qquad \text { (fold }) \frac{1}{2}\end{array}$ \\
\hline Kirchoff migration & constant velocity $2900 \mathrm{~m} / \mathrm{s}$ & to migrate steep dips \\
\hline
\end{tabular}

Table 1: Post-stack time migration

\begin{tabular}{|c|c|c|}
\hline Processing step & Parameters & Purpose \\
\hline Bandpass filtering & pass: $5-90 \mathrm{~Hz}$ & $\begin{array}{l}\text { broad frequency filtering before } \\
\text { deconvolution }\end{array}$ \\
\hline $\begin{array}{l}\text { Predictive deconvolution, shot } \\
\text { gather averaged }\end{array}$ & $\begin{array}{c}\text { pred. } 80 \text { ms, oper. } 500 \mathrm{~ms} \text {, averaged over gain } \\
\text { normalized } 33 \text { traces in a shot gather }\end{array}$ & removal of short period reverberation \\
\hline Tau-p velocity filter & $\begin{array}{l}\text { lower and upper pass (dip in ms): }-16 /-14 \\
\qquad / 14 / 16\end{array}$ & $\begin{array}{l}\text { steep dip noise removal, increase coherence } \\
\text { in shot gather }\end{array}$ \\
\hline Free surface multiple modeling & 2-D prestack Kirchhoff integral & simulation of free surface multiples \\
\hline $\begin{array}{l}\text { CMP sorting, NMO } \\
\text { over-correction }\end{array}$ & $\begin{array}{l}\text { over-correction: move-out in between primary } \\
\text { and multiple move out }\end{array}$ & $\begin{array}{l}\text { separation of primaries and multiple in the } \\
\text { FK-domain }\end{array}$ \\
\hline Trace interpolation & $\mathrm{F}-\mathrm{X}$ domain & remove spatial aliasing \\
\hline FK-filter & pass negative dips & Remove under corrected (multiple) events \\
\hline $\begin{array}{l}\text { NMO over-correction removal, } \\
\text { remove interpolated traces }\end{array}$ & NMO remove, kill traces & $\begin{array}{l}\text { generate uncorrected, original geometry } \\
\text { CMP-gather }\end{array}$ \\
\hline $\begin{array}{c}\text { Adaptive subtraction of modeled } \\
\text { free surface multiples }\end{array}$ & 1-D least square algorithm & $\begin{array}{l}\text { Removal of remaining free surface multiples } \\
\text { (not separated by move-out) }\end{array}$ \\
\hline $\begin{array}{l}\text { Geometrical spreading } \\
\text { compensation }\end{array}$ & primary NMO velocity & Gain correction \\
\hline $\begin{array}{l}\text { Time and spatial variant } \\
\text { frequency filter }\end{array}$ & $\begin{array}{l}\text { pass at seafloor: } 8-90 \mathrm{~Hz} \text {, pass } 4 \mathrm{~s} \text { below } \\
\text { seafloor: } 5-60 \mathrm{~Hz}\end{array}$ & $\begin{array}{l}\text { removal of remaining low and high } \\
\text { frequency noise }\end{array}$ \\
\hline $\begin{array}{l}\text { Kirchhoff pre-stack depth } \\
\text { migration with focusing and } \\
\text { residual move-out analysis }\end{array}$ & top to bottom velocity building, 6 Iterations & $\begin{array}{l}\text { velocity estimation to image the reflection at } \\
\text { the correct depth }\end{array}$ \\
\hline
\end{tabular}

Table 2: Pre-stack time migration 
References

Amodio-Morelli, L., Bonardi, G., Colonna, V., Dietrich, D., Giunta, G., Ippolito, F., Liguori, V., Lorenzoni, S., Paglionico, A., Perrone, A., Piccaretta, G., Russo, M., Scandone, P., Zanettin-Lorenzoni, E. and Zuppetta, A., 1976. L'arco Calabro-Peloritano nell'orogene Appenninico-Maghrebide. Memorie della Società Geologica Italiana, 17: $1-60$.

Argnani, A., 2000. The Southern Tyrrhenian subduction system: recent evolution and neotectonic implications. Annali di Geofisica, 43(3): 585-607.

Argnani, A., 2009. Evolution of the Tyrrhenian slab tear and active tectonics along the western edge of the Tyrrhenian subducted slab. in: van Hinsbergen, D.J. J., Edwards, M. A., Govers, R. (Eds.), Collision and Collapse at the Africa-Arabia-Eurasia subduction zone. Geological Society, Special Publication, 311, London, pp 193-212.

Argnani, A. and Bonazzi, C., 2005. Malta Escarpment fault zone offshore eastern Sicily: PlioQuaternary tectonic evolution based on new multi-channel seismic data. Tectonics, 24: TC4009, doi:10.1029/2004TC001656.

Avedik, F., Hirn, A., Nicolich, R., Olivet, J.L. and Sachpazi, M., 1996. "Single-bubble" marine source offers new perspectives for lithospheric exploration. Tectonophysics, 267: 57-71.

Baccheschi, P., Margheriti, L. and Steckler, M.S., 2007. Seismic anisotropy reveals focused mantle flow around the Calabrian slab (Southern Italy). Geophysical Research Letters, 34: L05302, doi:10.1029/2006GL028899.

Baccheschi, P., Margheriti, L., Steckler, M.S. and Boschi, E., 2011. Anisotropy patterns in the subducting lithosphere and in the mantle wedge: A case study-The southern Italy subduction system. Journal of Geophysical Research, 116: B08306, doi:10.1029/2010JB007961.

Baes, M., Govers, R. and Wortel, M.J.R., 2011. Subduction initiation along the inherited weakness zone at the edge of a slab: Insights from numerical models. Geophysical Journal International, 184, doi: 10.1111/j.1365-246X.2010.04896.x: 991-1008.

Bartolome, R., Contrucci, I., Nouze, H., Thiebot, E. and Klingelhoefer, F., 2005. Using the OBS wide-angle reflection/refraction velocities to perform a pre-stack depth migration image of the "single bubble" multichannel seismic: example of the Moroccan margin. Journal of Applied Geophysics, 57: 107- 118.

Billi, A., Barberi, G., Faccenna, C., Neri, G., Pepe, F. and Sulli, A., 2006. Tectonics and seismicity of the Tindari Fault System, southern Italy: Crustal deformation at the transition between ongoing contractional and extensional domains located above the edge of a subducting slab. Tectonics, 25: TC2006, doi:10.1029/2004TC001763.

Billi, A., Faccenna, C., Bellier, O., Minelli, L., Neri, G., Piromallo, C., Presti, D., Scrocca, D. and Serpelloni, E., 2011. Recent tectonic reorganization of the Nubia-Eurasia convergent boundary heading for the closure of the western Mediterranean. Bulletin de la Société Géologique de France, 182(4): 279-303.

Billi, A., Presti, D., Faccenna, C., Neri, G. and Orecchio, B., 2007. Seismotectonics of the Nubia plate compressive margin in the south Tyrrhenian region, Italy: Clues for subduction inception. Journal of Geophysical Research, 112: B08302, doi:10.1029/2006JB004837. 
Bortoluzzi, G., Ligi, M., Romagnoli, C., Cocchi, L., Casalbore, D., Sgroi, T., Cuffaro, M., Caratori Tontini, F., D'Oriano, F., Ferrante, V., Remia, A. and Riminucci, F., 2010. Interactions between volcanism and tectonics in the western Aeolian sector, southern Tyrrhenian Sea. Geophysical Journal International, 183: 64-78.

Catalano, S., Doglioni, C. and Merlini, S., 2001. On the Mesozoic Ionian Basin. Geophysical Journal International, 144: 49-64.

Cernobori, L., Hirn, A., McBride, J.H., Nicolich, R., Petronio, L., Romanelli, M. and STREAMERS/PROFILES Working Groups, 1996. Crustal image of the Ionian basin and its Calabrian margins. Tectonophysics, 264: 175-189.

Chamot-Rooke, N., Rangin, C., Le Pichon, X. and Dotmed Working Group, 2005. DOTMED - Deep Offshore Tectonics of the Mediterranean: A synthesis of deep marine data in eastern Mediterranean. Mémoire de la Société géologique de France \& American Association of Petroleum Geologists, special number, 177: 64 pp, 9 maps with CDROM.

Chiarabba, C., De Gori, P. and Speranza, F., 2008. The southern Tyrrhenian subduction zone: Deep geometry, magmatism and Plio-Pleistocene evolution. Earth and Planetary Science Letters, 268: 408-423.

Chiarabba, C., Jovane, L. and DiStefano, R., 2005. A new view of Italian seismicity using 20 years of instrumental recording. Tectonophysics, 395: 251-268.

Cifelli, F., Mattei, M. and Della Seta, M., 2008. Calabrian Arc oroclinal bending: The role of subduction. Tectonics, 27, TC5001, doi:10.1029/2008TC002272.

Cifelli, F., Mattei, M. and Rossetti, F., 2007. Tectonic evolution of arcuate mountain belts on top of a retreating subduction slab: The example of the Calabrian Arc. Journal of Geophysical Research, 112: B09101, doi:10.1029/2006JB004848.

Civello, S. and Margheriti, L., 2004. Toroidal mantle flow around the Calabrian slab (Italy) from SKS splitting. Geophysical Research Letters, 31: L10601, doi:10.1029/2004GL019607.

Clark, S.A., Levander, A., Magnani, M.B. and Zelt, C.A., 2008a. Negligible convergence and lithospheric tearing along the Caribbean-South American plate boundary at 64 degrees W. Tectonics, 27(6): doi:10.1029/2008TC002328.

Clark, S.A., Zelt, C.A., Magnani, M.B. and Levander, A., 2008b. Characterizing the Caribbean-South American plate boundary at $64^{\circ} \mathrm{W}$ using wide-angle seismic data. Journal of Geophysical Research, 113: B07401, doi:10.1029/2007JB005329.

D'Agostino, N., D'Anastasio, E., Gersavi, A., Guerra, I., Nedimović, M.R., Seeber, L. and Steckler, M.S., 2011. Forearc extension and slow rollback of the Calabrian Arc from GPS measurements. Geophysical Research Letters, 38: L17304, doi:10.1029/2011GL048270.

de Voogd, B., Truffert, C., Chamot-Rooke, N., Huchon, P., Lallemant, S. and Le Pichon, X., 1992. Two-ship deep seismic soundings in the basins of the Eastern Mediterranean Sea (Pasiphae cruise). Geophysical Journal International, 109: 536-552.

Dercourt, J., Zonenshain, L.P., Ricou, L.E., Kazmin, V.G., Le Pichon, X., Knipper, A.L., Grandjacquet, C., Sbortshikov, I.M., Geyssant, J., Lepvrier, C., Pechersky, D.H., Boulin, J., Sibuet, J.C., Savostin, L.A., Sorokhtin, O., Westphal, M., Bazhenov, M.L., Lauer, J.P. and Biju-Duval, B., 1986. Geological evolution of the Tethys belt from the Atlantic to the Pamirs since the Lias. Tectonophysics, 123(1-4): 241-315.

Devoti, R., Esposito, A., Pietrantonio, G., Pisani, A.R. and Riguzzi, F., 2011. Evidence of large scale deformation pattern from GPS in the Italian subduction boundary. Earth and Planetary Science Letters: 230-241, doi:10.1016/j.eps12011.09.034. 
Dewey, J.F., Helman, M.L., Turco, E., Hutton, D.H.W. and Knott, D.S., 1989. Kinematics of the western Mediterranean. in Alpine Tectonic. Eds. M.P. Coward, D. Dietrich and R.G. Park, Geological Society Special Publication, 45, London, 265-283 pp.

Doglioni, C., Innocenti, F. and Mariotti, G., 2001. Why Mt Etna? Terra Nova, 13: 25-31.

Faccenna, C., Becker, T.W., Lucente, F.P., Jolivet, L. and Rossetti, F., 2001a. History of subduction and back-arc extension in the Central Mediterranean. Geophysical Journal International, 145: 809-820.

Faccenna, C., Funiciello, F., Giardini, D. and Lucente, F.P., 2001b. Episodic back-arc extension during restricted mantle convection in the Central Mediterranean. Earth and Planetary Science Letters, 187: 105-116.

Faccenna, C., Molin, P., Orecchio, B., Olivetti, V., Bellier, O., Funiciello, F., Minelli, L., Piromallo, C. and Billi, A., 2011. Topography of the Calabria subduction zone (southern Italy): Clues for the origin of Mt. Etna. Tectonics, 30, TC1003, doi:10.1029/2010TC002694.

Faccenna, C., Piromallo, C., Crespo-Blanc, A., Jolivet, L. and Rossetti, F., 2004. Lateral slab deformation and the origin of the western Mediterranean arcs. Tectonics, 23: TC1012, doi:10.1029/2002TC001488.

Finetti, I., 1982. Structure, stratigraphy and evolution of Central Mediterranean. Bolletino di Geofisica Teorica ed Applicata, XXIV, ${ }^{\circ}$ 96: 247-312.

Frizon de Lamotte, D., Raulin, C., Mouchot, N., Wrobel-Daveau, J.C., Blanpied, C. and Ringenbach, J.C., 2011. The southernmost margin of the Tethys realm during the Mesozoic and Cenozoic: Initial geometry and timing of the inversion processes. Tectonics, 30: TC3002, doi:10.1029/2010TC002691.

Gallais, F., Gutscher, M.A., Graindorge, D., Chamot-Rooke, N. and Klaeschen, D., 2011. A Miocene tectonic inversion in the Ionian Sea (Central Mediterranean): evidence from multi-channel seismic data. Journal of Geophysical Research: doi:10.1029/2011JB008505.

Gallais, F., Gutscher, M.A., Graindorge, D. and Klaeschen, D., 2012. Two-stage growth of the Calabrian accretionary wedge in the Ionian Sea (Central Mediterranean): Constraints from depth migrated multi-channel seismic data. Marine Geology, 326328: 28-45.

Giardini, D. and Velona, M., 1991. The deep seismicity of the Tyrrhenian Sea. Terra Nova, 3: 57-64.

Govers, R. and Wortel, M.J.R., 2005. Lithosphere tearing at STEP faults: Reponse to edges of subduction zones. Earth and Planetary Science Letters, 236: 505-523.

Guarnieri, P., 2004. Structural evidence for deformation by block rotation in the context of transpressive tectonics, northwestern Sicily (Italy). Journal of Structural Geology, 26: 207-219.

Guarnieri, P., 2006. Plio-Quaternary segmentation of the south Tyrrhenian forearc basin. International Journal of Earth Sciences, 95: 107-118.

Guillaume, B., Funiciello, F., Faccenna, C., Martinod, J. and Olivetti, V., 2010. Spreading pulse of the Tyrrhenian Sea during the narrowing of the Calabrian slab. Geology, 38(9): 819-822.

Gvirtzman, Z. and Nur, A., 1999a. The formation of Mount Etna as the consequence of slab rollback. Nature, 401: 782-785.

Gvirtzman, Z. and Nur, A., 1999b. Plate detachment, asthenosphere upwelling, and topography across subduction zones. Geology, 27(6): 563-566.

Gvirtzman, Z. and Nur, A., 2001. Residual topography, lithospheric structure and sunken slabs in the central Mediterranean. Earth and Planetary Science Letters, 187: 117-130. 
Hirn, A., Nicolich, R., Gallart, J., Laigle, M., Cernobori, L. and Group, E.S., 1997. Roots of Etna volcano in faults of great earthquakes. Earth and Planetary Science Letters, 148: 171-191.

Hubral, P., 1977. Time Migration-Some ray theorical aspects. Geophysical Prospecting, 25: 738-745.

Kastens, K.A. and Mascle, J., 1990. The geological evolution of the Tyrrhenian Sea: An introduction to the scientific results of ODP Leg 107, in Kastens, K.A., and Mascle, J., Proceedings of the Ocean Drilling Program, Volume 107: College Station, Texas, Ocean Drilling Program, p. 3-26.

Lofi, J., Déverchère, J., Gaullier, V., Gillet, H., Gorini, C., Guennoc, P., Loncke, L., Maillard, A., Sage, F. and Thinon, I., 2011. Seismic Atlas of The "Messinian Salinity Crisis" markers in the Mediterranean and Black Seas, Commission de la carte géologique du monde et société géologique de France (Eds.), 1 C.D., 72 pp.

Loubrieu, B., Mascle, J. and Medipmap Group, 2007. Morpho-Bathymetry of the Mediterranean Sea. CIESM \& Ifremer Special Publications, 1:3.000.000 scale.

Lucente, F.P., Chiarabba, C., Cimini, G.B. and Giardini, D., 1999. Tomographic constraints on the geodynamic evolution of the Italian region. Journal of Geophysical Research, 104(B9): 20307-20327.

Makris, J., Nicolich, R. and Weigel, W., 1986. A seismic study in the Western Ionian Sea. Annales Geophysicae, 4(B6): 665-678.

Malinverno, A. and Ryan, W.B.F., 1986. Extension in the Tyrrhenian Sea and shortening in the Apennines as result of arc migration driven by sinking of the lithosphere. Tectonics, 5: 227-245.

Mattei, M., Cifelli, F. and D'Agostino, N., 2007. The evolution of the Calabrian Arc: Evidence from paleomagnetic and GPS observations. Earth and Planetary Science Letters, 263: 259-274.

Minelli, L. and Faccenna, C., 2010. Evolution of the Calabrian Accretionary wedge (Central Mediterranean). Tectonics, 29: doi:10.1029/2009TC002562.

Neri, G., Orecchio, B., Totaro, C., Falcone, G. and Presti, D., 2009. Subduction Beneath Southern Italy Close the Ending: Results from Seismic Tomography. Seismological Research Letters, 80, doi: 10.1785/gssrl.80.1.63(1).

Nicolich, R., Laigle, M., Hirn, A., L., C. and Gallart, J., 2000. Crustal structure of the Ionian margin of Sicily: Etna volcano in the frame of regional evolution. Tectonophysics, 329: 121-139.

Nicolosi, I., Speranza, F. and Chiappini, M., 2006. Ultrafast oceanic spreading of the Marsili Basin, southern Tyrrhenian Sea: Evidence from magnetic anomaly analysis. Geology, 34(9): 717-720.

Palano, M., Ferranti, L., Monaco, C., Mattia, M., Aloisi, G., Bruno, V., Cannavò, F. and Siligato, G., 2012. GPS velocity and strain fields in Sicily and southern Calabria, Italy: Updated geodetic constraints on tectonic block interaction in the central Mediterranean. Journal of Geophysical Research, 117, B07401, doi:10.1029/2012JB009254.

Piromallo, C. and Morelli, A., 2003. P wave tomography of the mantle under the AlpineMediterranean area. Journal of Geophysical Research, 108(B2): 2065, doi:10.1029/2002JB001757.

Polonia, A., Torelli, L., Mussoni, P., Gasperini, L., Artoni, A. and Klaeschen, D., 2011. The Calabrian arc subduction complex in the Ionian Sea: regional architecture, active deformation and seismic hazard. Tectonics, 30: TC5018, doi:10.1029/2010TC002821. 
Pondrelli, S., Salimbeni, S., Ekström, G., Morelli, A., Gasperini, P. and Vannucci, G., 2006. The Italian CMT dataset from 1977 to the present. Physics of the Earth and Planetary Interiors, 159: 286-303.

Rehault, J.P., Boillot, G. and Mauffret, A., 1984. The western Mediterranean Basin geological evolution. Marine Geology, 55: 447-477.

Rosenbaum, G. and Lister, G.S., 2004. Neogene and Quaternary rollback evolution of the Tyrrhenian Sea, the Apennines, and the Sicilian Maghrebides. Tectonics, 23: TC1013, doi:10.1029/2003TC001518.

Rosenbaum, G., Massimo, G., Lucente, F.P., Peccerillo, A. and Miller, M.S., 2008. Kinematics of slab tear faults during subduction segmentation and implications for Italian magmatism. Tectonics, 27: TC2008, doi:10.1029/2007TC002143.

Ryan, W.B.F., Kastens, K.A. and Cita, M.B., 1982. Geological evidence concerning compressional tectonics in the eastern mediterranean. Tectonophysics, 86: 213-242.

Scandone, P., Patacca, E., Radoicic, R., Ryan, W.B.F., Cita, M.B., M., R., Chezar, H., Miller, M.S., McKenzie, J. and Rossi, S., 1981. Mesozoic and Cenozoic rocks from the Malta Escarpment (Central Mediterranean). The American Association of Petroleum Geologists Bulletin, 65: 1299-1319.

Schellart, W.P., 2010. Mount Etna-Iblean volcanism caused by rollback-induced upper mantle upwelling around the Ionian slab edge: An alternative to the plume model. Geology, 38(8): 691-694.

Selvaggi, G. and Chiarabba, C., 1995. Seismicity and P-wave velocity image of the Southern Tyrrhenian subduction zone. Geophysical Research Letters, 121: 818-826.

Serpelloni, E., Anzidei, M., Baldi, P., Casula, G. and Galvani, A., 2005. Crustal velocity and strain-rate fields in Italy and surrounding regions: new results from the analysis of permanent and non-permanent GPS networks. Geophysical Journal International, 161: 861-880, doi:10.1111/j.1365-246X.2005.02618.x.

Serpelloni, E., Vannucci, G., Pondrelli, S., Argnani, A., Casula, G., Anzidei, M., Baldi, P. and Gasperini, P., 2007. Kinematics of the Western Africa-Eurasia plate boundary from focal mechanisms and GPS data. Geophysical Journal International, 169(3): 11801200 .

Speranza, F., Maniscalco, R. and Grasso, M., 2003. Pattern of orogenic rotations in centraleastern Sicily: implications for the timing of spreading in the Tyrrhenian Sea. Journal of Geological Society, London, 160: 183-195.

Speranza, F., Maniscalco, R., Mattei, M., Di Stefano, R., Butler, R.W.H. and Funiciello, R., 1999. Timing and magnitude of rotations in the frontal thrust systems of southwestern Sicily. Tectonics, 18(6): 1178-1197.

Westaway, R., 1993. Quaternary uplift of Southern Italy. Journal of Geophysical Research, 98(B12): 21741-21772.

Wortel, M.J.R. and Spakman, W., 2000. Subduction and Slab Detachment in the Mediterranean-Carpathian Region. Science, 290: 1910-1917.

Yilmaz, O., 1987. Seismic data processing, 2, Tulsa Oklahoma, U.S.A., 526 pp. 